\title{
Review on the Impact of Small Scale Irrigation Scheme on Household Income and Poverty Reduction in Ethiopia
}

\author{
Mideksa Dabessa Iticha \\ Jimma University College of Agriculture and Veterinary Medicine (JUCAVM), P.O.Box307, Jimma, Ethiopia
}

\begin{abstract}
This seminar paper reviews those papers done on small scale irrigation scheme by different researchers using cross sectional data. The contribution of irrigation to poverty reduction at household level all mostly explained in this seminar. The small-scale irrigation schemes with the objective of increasing agricultural productivity to reduce the poverty situation of the farming communities and to reduce dependence on the erratic rainfall. The impact of smallscale irrigation on income of rural farm households has positive as different study shows that. The levels of income of irrigation user and non-user households are widely different as observed from different studies. According to Sesen (2013) the study, indicated that, the average income of irrigation users were ETB 4003.21 and their nonirrigation also ETB 797 the average income difference between them was ETB 2720.88. Anwar(2014) study also shows that the mean per capita farm income for irrigating households was found $8548 \mathrm{ETB}$ and the non irrigating households was found in the range 5600-6150 ETB. On other hand factories influences farmers participation on small irrigation are: household head, access to extension, access to credit, availability of irrigable land, number of oxen, age, sex, education level, access to the water and family size have significant and positive effect. Access to good irrigation water contributes to socioeconomic uplifts of rural communities and alleviates poverty. These are production, income and consumption, employment, food security, and other social impacts contributing to overall improved social welfare. In general irrigation reduce poverty through increasing agricultural productivity, increasing household income, creating employment opportunity, stabilizing and reducing risk and by accesses to credit. Therefore, the government should be enhancing the expansion of small-scale irrigation to reduce poverty. Keywords: Agriculture, Ethiopia, Household, impact, income, poverty reduction, small scale irrigation.
\end{abstract}

DOI: $10.7176 / \mathrm{JESD} / 10-17-07$

Publication date:September $30^{\text {th }} 2019$

\section{Introduction}

Ethiopia is a poor country in the Horn of Africa where around $80 \%$ of the population depends on agriculture for their livelihood (Van Koppen et al., 2009). Agriculture is the source of the Ethiopian economy in terms of income, employment and generation of export revenue; as it accounts for about $80 \%$ of the population directly or indirectly engaged in it (MoFED, 2012). The sector contributes to national GDP (43\%), employment (80\%), supply of raw materials $(70 \%)$, government tax revenue $(28 \%)$ and export earnings $(85 \%)$ (CSA, 2012).

Ethiopian agriculture is highly depend on rain fed, under this condition of very changed rainfall and recurrent droughts, affects agricultural production and, hence, has adverse effects on the economy in addition to what occur know a day. In the same way, the World Bank (2006) estimated that especially hydrological variability currently costs the economy over one third of its growth potential and has led to a $25 \%$ increase in poverty rates. In addition to this, because of small landholding and dependence on natural factors of production, environmental degradation, population growth, low access to new agricultural technologies, traditional methods of cultivation, and low institutional support services; Ethiopian agriculture is largely based on subsistence farming(MoFED, 2012).Most of a time Ethiopia is the country known by chronic food insecurity due to, poverty, weak institutions, low agricultural productivity, low functioning markets and inconsistent policies (Yami and Snyder, 2012).

Ethiopia is the country endowed with huge water resources with 12 river basins with an annual runoff volume of 122 billion $\mathrm{m} 3$ of water and an estimated 2.6-2.65 billion $\mathrm{m} 3$ of groundwater potential (Awulachew et al., 2007; Makombe et al., 2011; MoA, 2011a). Due to this Ethiopia is considered to be the water tower of Africa (Makombe et al., 2007). However; the land currently under cultivation by irrigation is about 1.2 million ha (MoA, 2011a). Moreover, even if the potential and actual irrigated area is not precisely investigated (Belay and Bewket, 2013; Hayelom Desalegn, 2016), estimates of irrigable land in Ethiopia vary between 1.5 and 4.3 million hectares, averaged about 3.5 Mha.

Agriculture has high potential to reduce poverty and create employment for the rural poor since most are employed in it. However, this cannot be achieved without improving the agriculture water resources use. Due to that to overcome such problem, the Ethiopian government policy; strengthening public and private investment in irrigation development has been identified as one of the central strategies and to enable sustainable growth and development and also considered irrigation as of a basic tool to poverty reduction (World Bank, 2006; MoWR, 2002; MoFED, 2006). Given that agriculture is largely rain-fed, irrigation water has become a very important resource in agricultural production, and poverty reduction (Daniel, Z., 2015). In relation to this in East Asia the success full history of countries for instance China in the 1960s and 1970s in accommodating the growing 
population, achieving rapid economic growth and increasing employment, reducing the poverty through irrigated agriculture and eager the Ethiopian government to give more weight to the development of irrigation scheme (Bacha et al. 2011). Based on this, the federal and the regional governments associated with other international and local NGOs have significantly supported to rural farmers to participate and use irrigation farming. As a result, the irrigated farmland, irrigation production and the number of irrigation farmers in the country have notably increased, up to $80 \%$, between 1990 and 2010 (CSA, 2012).

There are three types of irrigation which are small scale irrigation $<200 \mathrm{hec}$, medium scale irrigation (200-300) hectare and large scale irrigation $>300$ hec.of land (MoWR, 2001). This seminar paper based on different literatures to address the use of irrigation especially the small scale irrigation and its power of poverty reduction through different indicators in Ethiopia. Irrigation is a very old practice, dating back to the earliest civilizations of humankind. It served as one of the key drivers behind growth in agricultural productivity, increasing household income and reduction of rural poverty, there by highlighting the various ways that irrigation influences on poverty (Anawar Alamin, 2014). Thus, irrigation especially small scale irrigation has an important development indicator for most developing countries like Ethiopia. There are four interrelated mechanisms by which irrigated agriculture can reduce poverty, including: 1) Increasing overall food production and income, which can also reduce food prices, each of which helps poor households meet their basic needs, 2) Protecting against risks of crop loss due to erratic, unreliable or insufficient rainwater supplies, 3) Promoting greater use of yield enhancing farm inputs and 4) creation of additional employment, which together enables people to move out of the poverty cycle( Hadush Hailu,2014). Irrigation contributes to increased value of agricultural production by increasing crop yields enabling farmers to increase cropping intensity and to produce higher-value crops (Ayale.et al., 2013). The Ministry of Agriculture, in Ethiopia, there were gives more emphases on modern and traditional water storage and water management systems for irrigation purposes. This includes water diversion schemes, water storage dams, micro irrigation systems, rainwater harvesting and shallow ground water harvesting techniques. These systems make use of different water drawing irrigation technologies for lifting, conveying and applying irrigation water for irrigation uses (MoA, 2011). Therefore, irrigation has un represent able technological intervention to increase household income. However, the impact of irrigation on income and the reduction of poverty in a particular setting is an empirical question. Also there are different socio economic factors that influences household participation in irrigation, there is high income difference between irrigation participant and non participant and the influence of irrigation on poverty through different indicators are in general can be those discussed through this seminar paper. More specifically, it is intended to make available information on the small scale irrigation and poverty are how inter related each other.

\subsection{Objective}

The general objective of this seminar paper is to review the impact of small scale irrigation scheme on the household income and poverty reduction at household level.

\section{The need for small-scale irrigation in Ethiopia}

In Ethiopia, irrigation has a long tradition (Mengistu, 2003). One of the main targets of irrigation systems is to fortunate agricultural production in qualitative as well as in quantitative meaning (Sesen Hadush, 2013). Harvests shall be enlarged so that people either produce enough food for the non-harvest time or to sell their overproduction and earn some money to buy food. In Ethiopia, there has been a practice of irrigation during the last decades in order to enhance rural development and food security (FAO/WFP, 2006). From them Small scale irrigation is most popular and preferred one. Small scale irrigation is preferred because of the easy adaptability of the systems to local environmental and socioeconomic conditions and also it is the mitigation for environmental degradation and absence of non farm income in rural. But more importantly, small scale irrigation has become important because of the recent shift in the development paradigm to 'development from below', an approach subsumed under 'sustainable development' (Adams 1990 in Aberra 2004 and Aziabah 2008 in Daniel.Z 2012).

Furthermore, small scale irrigation schemes are attractive because of the low capital investment required and the demonstrated capacity of the beneficiaries to manage, operate and maintain the systems (Tefesse 2003 in Muez 2014). Small scale irrigation can be highly productive in terms of yield per hectare of land. The energy input into large scale schemes can be up to fifteen times greater than that required in small scale schemes to produce the same output of crops ( Letitia. S, 2012). This is not to say that small scale irrigation is without challenges and difficulties. Some of these include: low levels of efficiency, lack of finance, inadequate marketing, and weak extension services among others. Based on above idea realizing the present socio-economic situations, it is evident that Ethiopia cannot meet it's reduce poverty objectives using the prevailing land and water use systems (Sesen Hadush, 2013). Then, this increased problem of food insecurity and increased poverty if sustainable solutions are not found in the future. But the solution is especially enhancing the small scale irrigation scheme at all parts of the country as the evidences shows. SSI schemes are the responsibility of the MoARD and regions (Awulachew, 2010). SSIS can be categorized into traditional schemes,modern diversion schemes,micro/medium dams,pumped 
scheme,micro irrigation and shallow ground water harvesting (MoA-NRMD, 2011).

\section{The income level of small scale irrigation scheme user and non-user households}

In Ethiopia as many studies have indicated that irrigation is positively correlated with household income and expenditure and negatively correlated with poverty. Those studies have confirmed that the probability of households with access to irrigation water being poor was significantly less than those with no access to irrigation water. As evidence shows from different studies first and most directly, where conditions are favorable irrigation can raise the incomes of those farmers with access to irrigation.

According to Sesen (2013) studies aboutthe impact of community managed irrigation on household income and poverty reduction in Tigirayshow that, irrigation has an impact on increasing household income and reducing poverty. The (PSM) result indicated that, the average income of irrigation users were ETB 4003.21 and their nonirrigation also ETB 797 the average income difference between them was ETB 2720.88, and hence there is influence mean income difference between irrigation users and non-users. According to Muez (2014) study aboutthe impact of small-scale irrigation on rural household food security in Tigiray shows that a small-scale irrigation scheme has a positive impact on householdse farm income and household food security using consumption expenditure as a proxy. The study also indicated that the annual farm income and food consumption expenditure per adult equivalent of the irrigation participants in 2012/2013 were respectively $48.9 \%$ and $36.4 \%$ higher than that of the nonparticipants.

According to Anwar (2014) study about impact of small scale irrigation on household welfare indicated that access to small-scale irrigation has a profound impact on improving the livelihoods of smallholder farmers. The PSM model results for the outcome variable per adult consumption expenditure indicated the average treatment effect on the treated was in the range of 1800-2400 ETB depending on the matching algorithm under consideration. The corresponding figure using the unmatched sample was calculated to be 2451 ETB. Assuming consumption expenditure as good proxy for welfare measurement, the review shows the standard of living of irrigating households is better than non irrigating households. Likewise, the mean difference for the outcome variable food expenditure in per adult was found to be in the range 1400-1900 ETB using the matched sample and 1913 ETB using the unmatched as the evidences of the result. Based on these review, it can be generalized that irrigating households are consuming more calories and hence have healthier standard of living than non irrigating households. Similarly, a positive impact in relation to the outcome variable per ca pita farm income. To be precise, while the mean per ca pita farm income for irrigating households was found 8548 ETB the corresponding figure for the non irrigating households was found in the range 5600-6150 ETB as the study shows. According to Getaneh (2011) studies about the impact of selected small-scale irrigation schemes on household income and the likelihood of poverty in the Lake Tana basin of Ethiopia, shows that irrigation is becoming a practice to increase total annual income for many households. His econometric analyses indicated that control for other factors that influence household income accesses to small-scale irrigation increases mean household income influence (about ETB 3,353 per year, or a $27 \%$ increase over non-irrigating households).

According to Kinfe Aseyehegn et al (2012) the journal of agricultural sciences shows that, keeping others constant, the total income of irrigation user households would be higher by Birr 26,593.60 than households who do not participate in irrigation farming. Irrigation allows farm households to use farm resource in a more productive way in at least two ways. First, it enables the production of vegetables and cereal crops twice and sometimes three times a year. Second, it helps improve livestock productivity by providing feed during the dry seasons and minimizing the cost of paying for fodder. Participation in small-scale irrigation, therefore, enables farm households to improve their well-being by not only allowing higher income but also minimizing risk and smoothening household consumption.

\section{Irrigation as estimation of poverty level via comparing of user and non user}

The poverty independences comparison between irrigation users and non-irrigation users has been performed using two poverty lines as the evidence from different studies indicate that. These are the extreme poverty line (basic consumption requirement poverty line) and moderate poverty lines. Extreme poverty line was estimated based on the cost of fulfilling the minimum calorie intake for a healthy life being 2,200 calories, while the moderate poverty line was derived based on a food poverty line of 2,750 calories (which is $125 \%$ of the 2,200 calories level); which is commonly used for welfare monitoring by the Ethiopian Central Statistics Agency (CSA, 2012). Based on the above evidence a recent study by Haji and Aman (2013) revealed that access to small-scale irrigation scheme have significantly reduced the relative frequency of occurrence of, the depth and the severity of households" poverty in Gorogutu District of Eastern Hararghe and irrigation is used for detect the poverty level. According to Nilsson et al. (2010), combined sample households (both irrigating and non-irrigating) are ranked according to their current income. This ranking is then used to determine which quartile a household is in based on current income. The households in the lower quartiles are relatively poor whereas those in the upper quartiles are relatively well off. On other hand studies Ayenew Adugna et al (2014) shows that a more of non-irrigating households (those have 
idle labor during irrigation time) have the lowest-income quartile.

According to Getaneh (2011) studies about the impact of selected small-scale irrigation schemes on household income and the likelihood of poverty in the Lake Tana basin of Ethiopia, an irrigation development has a profound impact in alleviating poverty. The poverty analysis indicates that a much higher proportion of those who are poor are non-irrigating rather than irrigating households. According to Sesen (2013) the study shows that poverty decomposition results by irrigation type establish that the incidence of poverty is influence lower among the sample population from irrigation users (12\%) compared with non-irrigation users (17\%). Poverty Gap Index was also small lower for irrigation user (1\%) irrigated plots than non-irrigation user farmers (5\%). Muez (2014) elaborate this idea the poverty incidence was higher among irrigation participants compared to non participants, with $35.5 \%$ of non-participants as the study shows that poor compared to $26.3 \%$ of irrigation participants. The depth and severity of poverty was higher among the non-irrigators than among irrigators. The poverty gap index is $8.2 \%$ for non-irrigators and $3.1 \%$ for irrigators. This implies that the current food consumption level of poor irrigation users and non-users would have to increase by an average of $8.2 \%$ and $3.1 \%$, respectively, to lift them out of poverty. According to Anwar (2014) study about impact of small scale irrigation on household welfare indicated that poverty analysis based on the absolute poverty line, $26 \%$ of non irrigating households were below the poverty line while the corresponding number for irrigating households was only 6\%. Similarly, the depth and severity of poverty were significantly higher for the non irrigation households as the study shows that.

\section{The impact and contribution of small scale irrigation scheme on poverty reduction}

\subsection{Influence of irrigation on agricultural production output}

As the result of different studies shows that irrigation has the positive influence on agriculture production. The evidences are as follow: According to Sesen (2013) studies about the impact of community managed irrigation on household income and poverty reduction in Tigiray show that irrigation has the first direct impact is on output levels. From a study of the impact of irrigation in Asia, Lipton and others came out that irrigation increases total farm output and hence, with unchanged prices, raises farm incomes. It was found by that study that increased output levels may arise for any of at least three reasons. Firstly, irrigation improves yields through reduced crop loss due to erratic, unreliable or insufficient rainwater supply. Secondly, irrigation allows for the possibility of multiple-cropping, and so an increase in annual output. Thirdly, irrigation allows a greater area of land to be used for crops in areas where rain fed production is impossible or marginal. According to Littita Sampoa (2012) evidence for these effects is widespread, well documented and uncontroversial. For example, the FAO suggests that irrigation can increase yields for most crops by 100 to $400 \%$, and that higher, less risky and more continuous levels of rural employment and income result from the higher cropping intensities, yields and more intensive and higher value crops and cultivation techniques of irrigated compared to rain-fed agriculture, when trying to come out with the influence of irrigation on farmers output, mentioned that irrigation enables the poor and smallholders to achieve higher yields and that the productivity of crops grown under irrigated conditions is often substantially higher than that of the same crops under rain fed conditions. Higher productivity helps to increase returns to farmers' endowments of land and labor resource. According to Hussain and Hanjra, access to reliable irrigation water can enable farmers to adopt new technologies and intensify cultivation, leading to increased productivity, overall higher production, and greater returns from farming.

According to Getaneh (2011) studies about the impact of selected small-scale irrigation schemes on household income and the likelihood of poverty in the Lake Tana basin of Ethiopia, shows that access to irrigation increases the opportunity for crop intensity and diversification, which increase cropping income and also increases crop productivity and stabilize the risk associated with crop. According to Anwar (2014) study indicated that access to water has enabled irrigating households to diversify cropping, to increase farming intensity, to minimize crop failure and hence to enhance productivity and farm income. Hadush Hailu (2014), elaborate the idea of Getaneh irrigation benefits the poor through higher production, higher yields, lower risk of crop failure and higher and year round farm and nonfarm employment. Irrigation enables smallholders to adopt more diversified cropping patterns, and to switch from low value staple or subsistence production of high value available and affordable for the poor. Since irrigation investments lead to production and supply shifts, indirect linkages operate through regional and national level and have a strong positive effect on the national economic growth benefiting the poor.

\subsection{Effect of irrigation on employment}

According to Littita Sampoa (2012) study shows that irrigation requires labor, labor employment and real wages rise slightly. But this labor demand effect on irrigation is not very strong due to the inelastic final demand, which curtails output. According to his report the second direct effect on poverty is via employment. There are two sources of additional demand for labor created by irrigation projects. Irrigation projects firstly require labor for construction and on-going maintenance of canals, wells and pumps etc. This is likely to be an important sector of employment for the poor, especially the landless rural poor or rural households with excess labor or seasonal excess labor. Secondly, increased farm output as a result of irrigation will stimulate demand for farm labor both 
within the main cropping season and across new cropping seasons, increasing both numbers of workers required and length of employment period.

According to Getaneh (2011) studies shows that rural poverty levels may therefore be reduced by increased employment opportunities. In addition there may be effects that extend to other areas if irrigation projects reduce migration to urban areas, and so reduce the pool of job-seekers and relieve the downward pressure on urban wages and the upward pressure on prices of housing and other urban infrastructure. According to Hadush Hailu (2014), study shows that irrigation benefits the poor by creating year round employment from farm and nonfarm. According to Kinfe Aseyehegn et al (2012) the journal of agricultural sciences shows that irrigation intensifies labor and is preeminent strategy of employment in countries like Ethiopia with elevated population growth rates. According to Manistie et al (2012) studies report the percentages of 47 and 72 of the irrigator households also responded that irrigation has the potential to increase employment opportunities to the nearby Poor people and increase participation in different community decisions of the irrigator societies of the study area, respectively. According to Eneyewet al (2014) conceptually, among the many benefits of irrigation, employment generation is crucial. The beneficiaries have shifted from once a year (rainy season) to two and three harvests and labor use efficiency were improved due to irrigation.

\subsection{Stabilization and risk reduction}

According to Getaneh (2011) studies about the impact of selected small-scale irrigation schemes on household income and the likelihood of poverty in the Lake Tana basin of Ethiopia, show that access to irrigation increases the opportunity for crop intensity and diversification, which increase cropping income and also increases crop productivity and stabilize the risk associated with crop. By making employment and incomes more reliable (as well as higher) irrigation protects farmers from loss of assets and also prevents peasants from getting into debttraps. In a bad monsoon, while rain fed crops may fail crops irrigated using groundwater usually yield well. Even if the groundwater table falls, it can recover during a more humid period. Thus, irrigation acts as a buffer against bad years and hence the deprivation and indebtedness that these years may entail. Risk of disposing of assets such as mortgaging or selling land to buy food or meet debts, are reduced. Daniel Ziba (2015) describes how irrigation by poor families with hand pumps has prevented them from becoming landless. Irrigation also liberates people from maintaining demeaning social relations such as with money-lenders. Lipton (2003) state that "for resource poor farmers and landless laborers alike, it ceases to be so necessary to 'touch the shoes of the rich' as insurance against those dreaded bad seasons or bad times of a year when food runs out and loans are needed to survive. "Irrigation thus supports self independence."

\section{Socio-economic factors affecting farmers' participation in small scale irrigation}

The evidence from different studies is show that; there are different socio-economic factories affecting farm household's participation in small scale irrigation schemes. Bacha et al. (2011) in the study of the impact of smallscale irrigation on household poverty in central Ethiopia, reported that land productivity, asset ownership, credit utilization, extension support, resilience to poverty, mean off-farm income, and mean food consumption and expenditure on food and non-food assets were significantly higher for irrigators than non-irrigators. Another opportunity to produce more food crops is irrigated gardening, an activity mainly done by women.According to Sesen (2013) study shows that family size, farm size and land holding, access livestock holdings, education level and amount of fertilizer used has a positively impact on contribution to household income and determine the participation in small scale irrigation.

According to anwar (2014) study about impact of small scale irrigation on household welfare indicated that from his descriptive analysis no significance difference observed between the participant and non participate in relation to the variables age of household head, size of cultivated land, number of adult labor and oxen holding in the same way, there was no significant difference in the number of adult labor between irrigating and non irrigating households, but it was found that irrigating households had less off farm income than their counter parts. By this, it can be generalized that irrigated farms have more labor absorbing tendency than non irrigated farms.

According to Muez (2014) study about the impact of small-scale irrigation on rural household food security in Tigiray shows that the main factors that explains rural households to participate in small-scale irrigation describes sex, education level, cultivated land holding, access to credit, access to extension service, distance to farmers training center and irrigation water availability of the household heads are the major factors that significantly influence the probability of rural households to participate in small-scale irrigation. These all variables are positively influenced the irrigation participation of the household heads in the as the study of him shows. For instance, the positive relationship access to credit and access to extension service with small-scale irrigation participation explained by the fact that the institutional credits and extension services gives an opportunity to households to participate in small-scale irrigation. The mean cultivated land size of small-scale irrigation users and non-users was 4.93 and 2.25 (tsimad) respectively according to him. This indicates that more access of cultivated land to irrigation user households enables them to participate in small-scale irrigation and 
generate more farm income than non-user. In the same way the average education level irrigation users and nonusers was 5.4 and 4.14(years) respectively. This show that one extra year of schooling to irrigation participants allows them to participate in small-scale irrigation schemes than non-participants.

\section{Conclusion and Recommendation}

7.1 Conclusion

Agriculture in Ethiopia is highly dependent on rainfall, which is highly erratic and unpredictable. The agricultural productivity of the farmers is very low and it is not able to reduce poverty due to the rain fall oriented farming system proceed and erratic rain fall. This makes the country to known by poverty for many years of a go. The productivity of rain fed agriculture is low and it is not possible to contribute to the overall development of the country. Ethiopian government's working hard on agricultural policies and strategies to improve the existing problem and the living standard of the rural population as shown by review. Currently, government provides special attention for agricultural sector by designing growth and transformation plan to come rapid economic growth throughout the country, and to be able the people poverty reduce and improves the living standard at household level and to set the country at middle level economic growth countries in the world in the next 15 to 20 years. This plan designed and starts to apply in the whole sectors throughout the country. From the plan designed this review is especially focus on irrigation development sector. As observed through this review there are three irrigation scales which are: small irrigation scale $(<2000)$, medium irrigation scale $(2000-3000) \&$ large irrigation scale $(>3000)$.From these irrigation scales, this review gives more emphases on small irrigation scale due to it is more practice at different level through the country.

Irrigation has the power of poverty reduction through increasing agricultural production and productivity, creating employment opportunity for poor on farm and off farm activity, increasing the income of irrigator, affecting the price of food and irrigation has negative impact on poverty and positive impact on income as the review shows that. As it is shown through this review those households accesses to irrigation (participate in irrigation) are more income and good living standard than those not accesses to irrigation. Those not accesses to irrigation are poor and many of them live under poverty line. However as shown in review there are factories affecting household participation in small scale irrigation such like sex, education level, cultivated land holding, access to credit, access to extension service, distance to farmers training center and irrigation water availability. Therefore small-scale irrigation (SSI), both directly and in-directly, has a great impact on enhancing farmers' income and poverty reduction through different dimensions, such as diversification of crops grown, stabilizing and risk reducing, as well as increased agricultural production and productivity, increasing household income, employment opportunity, access to credit and participation in community decisions.

\subsection{Recommendation}

The government should organize capacity-building activities to advance the farmers participation in small-scale irrigation to upgrade their existing indigenous way of working habit. Especially the great participation problem is with poor farmers.

The government and other body should enhance small irrigation; due to it has a power of mitigation frequently climate change and erratic rainfall and easily adaptable and workable at individual level.

Small- scale irrigation has a positive influence on income of rural farm households and has power of poverty reduction; in spite of this it has many constraints and its coverage is limited. So the government and other concerned body should work in expansion and enhance of its technological development.

There was the income gap between irrigation user and non user. The government and other concerned body should have to reduce the gap through by doing different activity.

Participation of household in small scale irrigation is influenced by different factors. The government or other concerned body should have to create awareness and providing such like credit service for buying seed or other input credit for the households.

At least mitigating the problems irrigation faces, creating awareness through training and extension and expansion of credit services are important factors to increase and improve in quality and amount of irrigation, and results to increase income and implication to reduce poverty.

At last but not least, the government and other concerned body should encourage researches on agriculture in general and irrigation in particular due to the irrigation has a power to reduce poverty.

\section{Reference}

Anwar, A.W., 2014.Impact of Small Scale Irrigation on Household Welfare.

APAM, L.S., 2012. An assessment of the impact of Small Scale irrigation schemes on livelihoods and poverty reduction in the Upper East Region (Doctoral dissertation, Department of Planning, Kwame Nkrumah University of science and Technology).

Awulachew, S.B., Merrey, D., Kamara, A., Van Koppen, B., Penning de Varies, F. and Boelee, E., 
2009. Experiences and opportunities for promoting small-scale/micro irrigation and rainwater harvesting for food security in Ethiopia (Vol. 98). IWMI.

Awulachew, S.B. and Merrey, J.D., 2007. Assessments of smalls scale irrigation and water harvesting in Ethiopian agricultural development. International Water Management Institute (IWMI), Addis Ababa, Ethiopia.

Awulachew, S.B., Merrey, D., Van Koopen, B. and Kamara, A., 2010, March. Roles, constraints and opportunities of small scale irrigation and water harvesting in Ethiopian agricultural development: Assessment of existing situation. In ILRI workshop (pp. 14-16).

Ayele, G.K., Nicholson, C., Collick, A.S., Tilahun, S.A. and Steenhuis, T.S., 2013. Impact of small-scale irrigation schemes on household income and the likelihood of poverty in the Lake Tana basin of Ethiopia. ILRI.

Bacha, D., Namara, R., Bogale, A. and Tesfaye, A., 2011. Impact of small-scale irrigation on household poverty: empirical evidence from the Ambo district in Ethiopia. Irrigation and Drainage, 60(1), pp.1-10.

Belay and Bewket, .2013.Implication of rural irrigation scheme on household economy. Chazovachii, B., 2012. The impact of small scale irrigation schemes on rural livelihoods: the case of Pangaea Irrigation Scheme Bikita District Zimbabwe. Journal of Sustainable Development in Africa, 14(4), pp.217-231.

CSA, .2012.Agricultural Sample Survey for Strategic Planning: Annual Report Federal Democratic Republic of Ethiopia Central Statistical Authority of Ethiopia: Annual Report, Addis Ababa, Ethiopia. http://www.csa.gov.et

Daniel, Z., 2015. The impact of irrigation schemes on farmers 'income and livelihoods in the upper east region of Ghana (Doctoral dissertation, Kwame Nkrumah University of Science and Technology).

Easton, Z.M., Fuka, D.R., White, E.D., Collick, A.S., Biruk Ashagre, B., McCartney, M., Awulachew, S.B., Ahmed, A.A. and Steenhuis, T.S., 2010. A multi basin SWAT model analysis of runoff and sedimentation in the Blue Nile, Ethiopia. Hydrology and earth system sciences, 14(10), pp.1827-1841.

Eneyew, A., Alemu, E., Ayana, M. and Dananto, M., 2014. The role of small scale irrigation in poverty reduction. Journal of Development and Agricultural Economics, 6(1), pp.12-21.

Getinet, K.A., 2011. Linking small-scale irrigation and household food (Doctoral dissertat, aau).

GW-MATE., 2011. Ethiopia: Strategic Framework for Managed Groundwater Development. GW-MATE (Groundwater Management Advisory Team) in Cooperation with Ethiopian Ministry of Water Resources, MetaMeta, Acacia Water and Nuffic.

Hadush, H., 2014. Adoption and Impact of micro Irrigation on Household Income: The case of Eastern Tigray (Doctoral dissertation, Mekelle University).

Haji, J., Aman, M. and Hailu, T., 2013. Impact analysis of Mede Telila Small Scale Irrigation scheme on house poverty Alleviation: Case of Gorogutu District in Eastern Haratghe Oromia National Regional State Ethiopia. International Journal of Development and Economic Sustainability, 1(1), pp.15-30.

Hayelom, D., 2016. Assessing factor affecting the adoption of rain water harvesting practices, in chamuk kebele, Moyale woreda, Somali regional state of Ethiopia (Doctoral dissertation, Addis Ababa University).

Husain, I. and Hanja, M.A., 2004. Irrigation and poverty alleviation: review of the empirical evidence. Irrigation and Drainage, 53(1), pp.1-15.

Kassahun, H.T., Nicholson, C.F., Jacobsen, J.B. and Steenhuis, T.S., 2016. Accounting for user expectations in the valuation of reliable irrigation water access in the Ethiopian highlands. Agricultural Water Management, 168, pp.45-55.

Kinfe Aseyehegn,et al,.2012.Effect of small-scale irrigation on the income of rural farm households: the case of laelay maichew district, central tigray, Ethiopia.

Lipton, .2003. The effects of irrigation on poverty: A Framework for Analysis. Journal of Water Policy, 5 (2003).

Mengistie, D. and Kidane, D., 2016. Assessment of the impact of small-scale irrigation on household live improvement at Gubalafto District, North Wollo, Ethiopia. Agriculture, 6(3), p.27

MoA-NRMD, .2011. Small-Scale Irrigation Situation Analysis and Capacity Needs Assessment (A Tripartite Cooperation between Germany, Israel and Ethiopia) Addis Ababa, Ethiopia.

MoFED, .2013. Development and Poverty in Ethiopia 1995/96-2010/11. Addis Ababa, Ethiopia.

MoFED, .2006. Ethiopia: Building on Progress. A Plan for Accelerated and Sustained Development to End Poverty 2005/6 - 009/10. September 2006..

MoWE,. 2012. Water Resources Management and Irrigation Policy: Annual Report of MOWE, Addis, Ethiopia.

Muez, H.A., 2014. The Impact of Small-Scale Irrigation on Rural household Food Security. The case of Emba Alaje woreda (Doctoral dissertation, Mekelle University).

Namara, R., Makombe, G., Hagos, F. and Awulachew, S.B., 2008. Rural poverty and inequality in Ethiopia: does access to small-scale irrigation make a difference?

Regassa, A.E., 2016. Determinants of agro pastoralists' participation in irrigation scheme: the case of fentalle agro pastoral district, oromia regional state, Ethiopia. International Journal of Agricultural Research, Innovation and Technology, 5(2), pp.44-50. 
Sesen, H.G., 2013. The Impact of Community Managed Irrigation on Household Income and Poverty Reduction: The Case of Sehartisamre Wereda, Tigray, Ethiopia (Doctoral dissertation, Mekelle University).

Thompson, J. and Scoones, I., 2009. Addressing the dynamics of agri-food systems: an emerging agenda for social science research. Environmental science \& policy, 12(4), pp.386-397.

World Bank, .2006 cited by Hagos, Fitsum, Godswill Makombe, Regassa E. Namara, and Seleshi Bekele Awulachew. "Importance of Irrigated Agriculture to the Ethiopian."

Yami, M. and Snyder, K., 2012. Improving sustainability of impacts of agricultural water management interventions in challenging contexts. Project report, International Water management Institute, Addis Ababa (Ethiopia). 